\title{
Inclusive Growth through Public and Private Participation: A must in Agriculture Sector in India
}

\author{
Prof. Pearly Jerry \\ (Head, Department of Management Studies, St. Aloysius Autonomous College, Jabalpur, India.)
}

\begin{abstract}
India being an agro based economy with the second highest farm output in the world needs more sustainable growth in this area. The public private partnership is one step towards attaining holistic growth. The government alone is not the answer to everything, the need is more than the capital investment. This paper is an effort to propose the possibilities of PPP in the field of agriculture.

Key Words: Agriculture, inclusive growth, Public private partnership, sustainable growth
\end{abstract}

\section{Introduction}

The need of sustainable growth from the grass root level has become the dire necessity of time. India ranks second worldwide in the farm output. The agriculture sector accounted for 17 per cent of India's gross domestic product (GDP). The food grain production during 2011-12 was 257.4 million tons. As per this indicator, the sector's importance to the economic, social and political fabric of the country cannot be undermined. Two third of India's population is depended on agriculture and related activities for their livelihood. This sector is the backbone of the nation and therefore to have a sustainable and inclusive growth the focus of investment should be moved towards the agriculture and the allied sectors. In the last two decades the agricultural related growth has been slower than in the non agricultural sector contributing to the widening of inequality. The masses of marginalized stay in our villages and they comprise the labor force of the agriculture sector.

The fundamental directive of our constitution specifies that bridging the gap between the rich and poor is the foundation of our nation. The rich have become richer the middle class has become strong economically but the poor have become poorer. The poverty line of our nation has become darker and grossly. When we consider these things, the answer is not, that the poor be given solace with a piece of bread and wait for another turn when another piece of bread will be thrown in front of them in mercy, but rather to build their confidence, sustenance and educate them through proper work opportunity, employability skills and build in entrepreneurial capability. But apart from all these the greatest problem remains that these programmes provide benefit to only a few even amongst the huge crowd of the marginalized. The major group of people out of ignorance of these programmes are lost in the crowd, thus the benefit does not reach them. It is thus the public private partnership is required to reach the marginalized, the forgotten masses and pull them in to the main stream.

The government alone with its machinery cannot reach to each every corner of our nation but with the help of many social service institutions, private undertakings and NGO's can actually reach the unreached. In today's context when we are raising such a hue and cry to improve the system and erase corruption we must consider in an open glass frame and that we ourselves should see and do things without our own personal agenda to bring a sustainable growth in our country. The need of today is to mobilize the youth to think rationally and compassionately to help the marginalized grow and develop. The need to improve agriculture productivity and sustainability is well-recognized in India's Twelfth Five Year Plan which aims at increasing agricultural GDP growth to $4 \%$ per annum from its current rate of 2.5\% (Planning Commission, 2011).

\section{The Statistics}

Crop yield per unit area of all crops have grown since 1950, due to the special emphasis placed on agriculture in the five-year plans and steady improvements in irrigation, technology, application of modern agricultural practices and provision of agricultural credit and subsidies since the Green Revolution in India. However, international comparisons reveal the average yield in India is generally $30 \%$ to $50 \%$ of the highest average yield in the world. India receives an average annual rainfall of 1,208 millimetres (47.6 in) and a total annual precipitation of 4000 billion cubic metres, with the total utilizable water resources, including surface and groundwater, amounting to 1123 billion cubic metres. 546,820 square kilometres $(211,130 \mathrm{sq} \mathrm{mi})$ of the land area, or about $39 \%$ of the total cultivated area, is irrigated. India's inland water resources including rivers, canals, ponds and lakes and marine resources comprising the east and west coasts of the Indian ocean and other gulfs and bays provide employment to nearly six million people in the fisheries sector. In 2008, India had the world's third largest fishing industry. India is the largest producer in the world of milk, jute and pulses, and also 
has the world's second largest cattle population with 175 million animals in 2008. It is the second largest producer of rice, wheat, sugarcane, cotton and groundnuts, as well as the second largest fruit and vegetable producer, accounting for $10.9 \%$ and $8.6 \%$ of the world fruit and vegetable production respectively. India is also the second largest producer and the largest consumer of silk in the world, producing 77,000 million tons in 2005. Population pressure, inheritance laws and a lack of employment opportunities in rural areas have contributed to both an increase in the number of farmers as well as a decrease in the average farm size (to around $1.23 \mathrm{ha}$ ). Agriculture-related growth has also been uneven across regions reflecting structural differences in land availability, population growth

Public extension services in the agricultural sector have not kept pace with new challenges and opportunities. Overall, the reform measures initiated by the government are yet to penetrate agriculture and allied rural sectors. While many state governments have ushered in policy and legislative changes, lack of clarity on basic models, regulatory mechanisms and modalities for the involvement of non-state actors continues. Insofar as the delegation of power to local governance institutions is concerned, often the measures suggested are partial or incremental in nature. The attitude towards a role for the organized business sector is by and large negative despite the fact that a number of business enterprises have built impressive capacities and networks in input supply and extension services.

\section{The Paradigm Shift}

The small farmers are now understanding their power and participation in the nation building. In the recent years, farm mechanization has witnessed growing importance, which is steadily helping in increasing the land and labor productivity in the country Mechanical equipments for various farm operations such as sowing, tillage, irrigation, threshing etc are being used by the farmers throughout the country. Even the small farmers are adopting modern technology for efficient farm management. Food packaging in India is also witnessing significant changes, with companies increasingly using it as an important vehicle for product differentiation. With the changes in food consumption patterns and demographics, the consumers are increasingly turning towards ready-to-eat and packaged foods. The packaging sector is being driven by trends such as freshness and improved shelf life, convenience of usage, packing to position and promote the brands and sustainability.

\section{The Development}

The budget also allocated US\$135 million to the Food Processing Ministry from the existing US\$ 90 million. As a measure to boost investment in agriculture the minister extended the Viability Gap Funding Scheme (VGFS) for public private partnerships (PPP) for setting up modern storage capacity besides giving infrastructure status to cold chains.

An integrated strategy for promotion of agribusiness Vision, Strategy an Action Plan for the Food Processing Sector has also been approved by the Government. Vision 2015 was announced by the Government of India, which suggested the strategy to ensure faster growth of the food processing sector. The Vision 2015 provides for enhancing the level of processing of perishable to 20 per cent, enhancing value addition to 35 per cent.

100 per cent foreign direct investment (FDI) is allowed under automatic route in Floriculture, Horticulture, Development of Seeds, Animal Husbandry, Pisciculture, Aquaculture and Cultivation of Vegetables and Mushrooms under controlled conditions and services related to agro and allied sector. Besides the above, FDI is not allowed in any other agricultural sector/activity, according to the Department of Industrial Policy and Promotion's (DIPP), consolidated FDI Policy. 100 per cent Foreign Direct Investment is allowed under automatic route in storage and warehousing including warehousing of agriculture products with refrigeration (cold storage). A new framework by India's ministry of agriculture to encourage private-public partnerships may open up opportunities for entrepreneurs in the farm sector. Under the new scheme, such PPP projects will be supported by government funds provided to states under the Rashtriya Krishi Vikas Yojana (RKVY). The scheme envisages an average investment of Rs 1 lakh per farmer, half of which will have to be put up by the private partner. It is known that more than $80 \%$ of farmers belong to the categories of small and marginal farmers with an area share of more than $40 \%$. The support systems and policy changes have to support in raising productivity and incomes of the small and marginal farmers. National Commission on Enterprises for Unorganized Sector suggests special programmes for small and marginal farmers. Principal activities proposed under this include promotion of marginal-small farmers groups, enabling greater access to institutional credit, training and capacity building, support for strengthening and non-farm activities, gender-focused activities and planning for development of marginal and small farmers. 


\section{The Proposition}

The public and private partnership sustainable inclusive growth model can become a 'in thing' if it is well designed and well programmed. According to the National PPP Policy 2011 "Government of India is committed to improving the level and the quality of economic and social infrastructure services across the country. In pursuance of this goal, the Government envisages a substantive role for Public Private Partnership (PPPs) as a means for harnessing private sector investment and operational efficiencies in the provision of public assets and services."

Opportunity to increase investments and productivity through micro finance and government productivity in the areas of milch animals, horticulture and fisheries by training the farmers. Envisaging public investments in providing water resources and creating suitable access for farmers while private investments create various support services in agriculture. Specifically, public investments are required for infrastructure creation aimed at water harvesting and recharge. Private investments could provide water delivery and irrigation services, farm mechanization services, agri-inputs, insurance and risk management, credit access, and market linkages. A business organization for parking private investments and groups of local semi literate youth for actually delivering the support services are important parts of this model. The institutional mechanism at the community level includes water user groups and community-based organizations for governance of water and other natural resources. The panchyats can be a platform for initiating such programmes. Some poorest of the poorest villages should be taken as the experiment group and the model to be implemented and their results seen.

Eighty-eight per cent of small farmers own almost 50 per cent of cultivated land and more than 50 per cent of irrigated land. They lease-in more than 30 per cent cultivated land (mostly irrigated). The vast network of Agricultural Universities and Colleges can play a leading role in cultivating self-confidence and capabilities in the students required for taking up agriculture as a profession.

1. Participation of investment in the areas of agricultural research and education.

2. Mobilization of resources and participation in farm mechanization.

3. Participation in post harvest and seed management areas.

4. Animal husbandry, fodder and water harvesting are the areas where technology and resources are needed.

5. Storage, packaging and warehousing are the areas which are investment intensive.

6. Increase investment in supply chain system

7. Participation in development of water resources and irrigation management institutions.

8. Stop farm land procurement and misuse of farmland for commercial purposes.

9. Opening up for the foreign investment in the agriculture sector.

\section{Conclusion}

Indian economy is the future of the world and all the nations will be eyeing it very closely. Therefore to renew the commitment of the nation to achieve the high standards of agriculture production, a call for public private partnership is must. There are many areas in which government alone cannot get success but the leading of government policies and growth at the grassroots level can be achieved through participative work. The call for investments in this area by the Foreign direct investment, government machinery and standardization of the mechanism can be done only through the participative mechanism. High standard of technology, training and expertise in agricultural area will help in inclusive growth.

\section{Journal Papers}

\section{References}

[1] OECD "Better policies" Series INDIA-Sustaining high and inclusive growth ; October 2012. National PPP Policy 2011- Draft for Consultation.

[2] The Economic Times, Agricultural Ministry release on PPP under Rashtriya Krishi Vikas Yojana, August $17,2012$.

[3] Vijay Paul Sharma, Accelerating agriculture development for inclusive growth: Strategic issues and policy options; Vikalpa, Vol. 37, No.1, January- March 2012

Proceeding Papers

[4] S. Mahendra Dev, Policies for raising Agricultural growth and Productivity in India, Indira Gandhi Institute of Development and Research, Mumbai, IGIDR proceedings, January 2012. 